\title{
PERCEPTIONS OF ADOPTERS ON THE USE OF COCOA TECHNOLOGIES IN EKITI STATE
}

\author{
Julius Olumide Ilesanmi, Oluwatosin Olaniyi Ojo \\ Department of Agricultural Education, School of Technical and \\ Vocational Education, College of Education, Ikere, Nigeria \\ DOI: https://doi.org/10.51193/IJAER.2020.6601
}

\begin{abstract}
The study investigated the perceptions of adopters on the use of cocoa technologies in Ekiti State, Nigeria. Specifically, it examined the socio economic characteristics of the cocoa farmers in the study area; identified the various technologies practiced by cocoa farmers; ranked the perception of the farmers towards the use of the technologies and examining the major constraints militating against the use of cocoa technologies. A multi-stage sampling technique was used to select sixty (60) respondents in four (4) local government areas namely: IrepodunIfelodun LGA; Oye LGA; Ekiti South West LGA and Ise/OrunLGA; which were predominated with cocoa farmers. Technology Perceptive Use Index (TPUI) was employed to access the extent of use of the cocoa technologies by the farmers of which $12.99 \%$ of the farmers use cultural maintenance practice to increase production of cocoa and this is most prominent among the farmers in the study area. This is closely followed by the use of fungicides and insecticides and the use of information sources on new methods to improve cocoa production respectively in which 12.91 and $12.56 \%$ agreed to these technologies respectively. Moreover, a good number of respondents $(11.35 \%)$ indicated that adopting all the technologies will definitely boost cocoa production. The least cocoa technology where farmers' perception is very low is the cutting of the old cocoa trees of which only $4.55 \%$ of the respondents indicated its usage. About $28.02 \%$ of the respondents identified high cost of adoption as a constraint and this was ranked first among others constraints identified by respondents in the study area.
\end{abstract}

Keywords: Adoption, Cocoa, Perception, Adopters, Technologies.

\section{INTRODUCTION}

Cocoa production is important to the economy of Nigeria. Cocoa is the leading agricultural export of the country and Nigeria is currently the world's fourth largest producer of Cocoa, after 


\section{International Journal of Agriculture and Environmental Research}

Volume: 06, Issue: 06 "November-December 2020"

Ivory Coast, Indonesia and Ghana, (FAO, 2013) and the third largest exporter, after Ivory Coast and Ghana.( Verter, N. and Bečvářová, V. 2014).

Cocoa flourishes in areas that are not more than 20 degrees north or south of the equator. (OforiBoateng, K. and Insah, B., 2014). The trees respond well in regions with high temperature and distributed rainfall. The cultivation of cocoa is done by many small scale farmers on farmlands of around two hectares while export is dominated by a few firms. (Ajetomobi, J. O., 2014).

The issue of depletion in cocoa production has generally affected all West African countries even in the face of innovation adopted to cater for the low output in cocoa production. Moreover, focussing on Nigeria, pests and diseases have largely contributed to the declining productivity of cocoa over the years. About $25-30 \%$, loss in yield of cocoa has been attributed to the cocoa Sahlbergella singularis. Seventeen percent was lost through the feeding of the cocoa pod borer Characoma strictigrapta while losses attributable to the major disease of cocoa (the black pod disease caused by Phytophtora megakarya) range from $30-90 \%$ in Nigeria (Oluyole and Lawal, 2008). The estimated farm holdings of peasant farmers account for $90 \%$ of the 700,000 hectares of land under cocoa cultivation. Also, many farms are poorly maintained, neglected or completely abandoned and with scattered stands. This has drastically reduced the effective hectarage of cocoa in Nigeria to 300,000 - 500,000 hectares thereby bringing down the potential yield realizable from the use of available improved technologies from $1,500 \mathrm{~kg}-3,000 \mathrm{~kg}$ dried beans per hectare to the current average yield $500 \mathrm{~kg} / \mathrm{ha}$, which is far below the genetic potentials of the crop (Ndubuaku and Asogwa, 2006).

All cocoa technologies are expected to be adopted and use accordingly in order to attend to the declining productivity; such as fertilizer usage and application; genetic improved seedlings; use of improved agrochemicals; adoption of improved spacing; shade reduction; harvesting techniques; fermentation and drying technologies etc (Oluyole et al. 2011). Adequate use of fertilizer has been found to increase agricultural output (Oguntade et al., 2009). According to Olson (1970), fertilizer could increase food production by at least 50\%. Opeyemi et al, (2005) reported that an effective use of fertilizer on cocoa would help not only to improve yield but also has the advantages of profitability, product quality and environmental protection. Agbeniyi et al (2010) observed in the study of fertilizer use and cocoa production in Cross River State that $98.13 \%$ of the respondents did not use fertilizer for cocoa production while just $1.87 \%$ of the respondents indicated that they are using fertilizer for cocoa production. The result is in line with Oguntade et al, (2009) which reported that $78.2 \%$ of cocoa farmers in Nigeria were not using fertilizer for cocoa production.

Apart from this, ageing of the cocoa trees is another factor that should necessitate farmers to adopt new technologies (Ojo, 2005). Opeke (2003) revealed in his study that most cocoa trees in 
International Journal of Agriculture and Environmental Research

ISSN: 2455-6939

Volume: 06, Issue: 06 "November-December 2020"

the tropical zones have stayed over 30 years and this has led to consecutive depletion of the soil nutrients over the years; invariably leading to low production in the total output of cocoa in the tropics. It was thereby observed in most studies that farmers did less or nothing in replacing the nutrients of their cocoa plantation. Moreover, adopting the genetic improved seedlings which are quite resistant to diseases and which can improve production as per fruiting will definitely improve production. However, the process of adoption on this level entails the farmers to cut down the old cocoa trees to ensure spacing for the new improved seedling to survive (Vos and Krauus, 2004). In this regard the farmers are resistant to this motive because adopting this technology will cut down their production for about ten years. Also, the issue of tenancy and the practiced tenure system have led to land fragmentation which otherwise does affect the adoption of planting new improved seedlings in replacement of the old trees since there are no available land accessible to the farmer for production (Mwanga et al., 1998).

Earlier efforts to improve the performance of the cocoa sector focused on land area expansion, however, studies on adoption of improved cocoa technologies have now been performed for decades (Arndt, Jones, and Tarp 2007). Moreover, more studies (Akintelu S. O. et al., 2019; Ilesanmi J. O. and Afolabi J. A, 2020) had revealed the intensification of the adoption of cocoa improved technologies. In view of these, this study centers toward examining the perception of the farmers using cocoa technologies and also identifies the constraints militating against consistent use of the technologies among the farmers.

\section{METHODOLOGY}

\subsection{Study Area}

The study was conducted in Ekiti State which is in the Southwest region of Nigeria located between latitudes $7^{\circ} 25^{\prime}$ and $80^{\circ} 5^{\prime} \mathrm{N}$ and between longitudes $4^{\circ} 45^{\prime}$ and $5^{\circ} 46$ east of the equator. Ekiti State is one of the fourteen states that are majorly involved in cocoa production in Nigeria. The state is bounded in the north by Kwara State and Kogi State while Osun State occupies the west and Ondo State lies in the south and extends to the eastern part. Ekiti State has 16 LGAs with an overall population of about 2,210,957 people (National Population Census, 2006) that spread over an approximately 6,353sq Km. Ekiti State is a landlocked state, having no coastal boundary. Moreover, the land is buoyant in agricultural resources with cocoa as its leading cash crop. Ekiti State contributed well over $40 \%$ of the cocoa products and this was largely known in the famous old Western Region (Wikipedia, 2010). Also, due to the favourable climatic conditions, the land enjoys luxuriant vegetation which brings abundant resources of different species of timber. Crops like yam, cassava and grains like rice and maize; with the inclusion of notable crops like kola nut and varieties of fruits are grown in commercial quantities. (Wikipedia, 2010) 
International Journal of Agriculture and Environmental Research

ISSN: 2455-6939

Volume: 06, Issue: 06 "November-December 2020"

\subsection{Sampling Technique}

The technique used for the study was Multi-stage sampling technique in four Local Government Areas (LGAs) which are preponderated with cocoa farmers. Ekiti State was selected for the study being one of the cocoa producing states in Nigeria and the LGAs that were selected out of the sixteen LGAs in the state are Irepodun-Ifelodun; Oye; Ekiti South West; and Ise/Orun. Structured questionnaire coupled with interview were used to collect data. The study also involved random selection of fifteen respondents from each LGA to give a total of sixty respondents from the study area and about 2 to 6 villages within LGAs were selected based on their involvement in cocoa production and for even distribution.

\subsection{Method of Data Collection}

Primary data were used for this study. Primary data relating to socioeconomic characteristics, perception of adopters on the use of cocoa technologies and other relevant issues were collected. The data were collected using quantitative approach by means of one-on-one contact survey.

\subsection{Method of Data Analysis}

Descriptive statistics such as frequency, percentage, mean, median and standard deviation was used to analyze the socioeconomic characteristics of the cocoa farmers in the study area. The Likert Scale model was employed to identify the perception of the adopters on the use of cocoa technology packages adopted in the study area; and based on the response of the adopters towards the constraints militating against adoption of the cocoa technologies; the frequency of their response was also used to identify the ranking of the constraints.

\subsection{Technology Perceptive Use Index (TPUI)}

This was employed to access the extent of use of the improved cocoa technologies by the cocoa farmers. The knowledge of this allows a better understanding of the possible area(s) of intervention either by government or other stakeholders in the area. In analyzing the extent of use of any of the improved cocoa technologies by the farmers, technology perceptive use index (TPUI) was developed by ranking. The extent of use of the TPUI was expressed using a fivepoint scale with the scoring order 5, 4, 3, 2, and 1 for strongly agree, agree, undecided, disagree and strongly disagree respectively. The formula used to obtain the TPUI score was adapted from Islam and Kashem (1999), where they estimated the use of Ethno-veterinary medicine in livestock management and rearing. Oluwatayo (2009) also specified on the Coping Strategy Use Index in ranking the strategies used by the household on food security. These were modified to obtain the TPUI as: 
$T P U I=N_{5} X_{1}+N_{4} X_{2}+N_{3} X_{3}+N_{2} X_{4}+N_{1} X_{5}$

Where:

TPUI $=$ Technology Perceptive Use Index

$\mathrm{N}_{5}=$ Number of Cocoa farmers strongly agree to TPUI

$\mathrm{N}_{4}=$ Number of Cocoa farmers agree to TPUI

$\mathrm{N}_{3}=$ Number of Cocoa farmers undecided to TPUI

$\mathrm{N}_{2}=$ Number of Cocoa farmers disagree to TPUI

$\mathrm{N}_{1}=$ Number of Cocoa farmers strongly disagree to TPUI

$\mathrm{X}_{1}=$ Scale point for strongly agree

$\mathrm{X}_{2}=$ Scale point for agree

$\mathrm{X}_{3}=$ Scale point for undecided

$\mathrm{X}_{4}=$ Scale point for disagree

$\mathrm{X}_{5}=$ Scale point for strongly disagree

The TPUI was used in ranking order to reflect the relative position of each of the TPUI in terms of farmers' perceptions towards the improved technologies used. The extent of use of the TPUI was then obtained for all cocoa farmers in the study areas.

\section{RESULTS AND DISCUSSION}

\subsection{Socio Economics Characteristics of the Farmers}

In Table 1, the result showed that the mean age of the sampled cocoa farmers was 51 years. Most of the respondents were adults and thirty percent of the respondents accounted for the age range between 20 and 39 years which are mainly classified as the youth in the communities. In the sum, the leading percentages of age range which belong to the active segment of the population take $65 \%$ of the respondents while the depending class makes up $35 \%$ of the farmers. The gender composition of the respondents is an important factor in determining availability for farm work and gender role in the study area and the males were preponderant. About $28.33 \%$ of the respondents were traders while the civil servants $(30.00 \%)$ have the highest percentage denoting that most of the farmers have a constant income to support their farm work. Most of the farmers 
also agree to the response of having subordinated man power to assist them on their cocoa plantation and above half of the adopters hired labour while only $33.33 \%$ of the adopters said they engaged family labour in farming. About $40.00 \%$ of the respondents adopted planting improved seedlings on their farms; and this aligned with the study of Lawal and Oluyole, (2008) as one of the factors that lead to low production level; in the sense that land fragmentation might not allow the farmers to plant the improved seedlings that can boost their production. In response to the frequency of application of fungicides and insecticides; $46.67 \%$ of the cocoa farmers spray their farms up to four times before harvesting while only $5.00 \%$ of the respondents sprayed either once or 2 times. About $50 \%$ of the respondents were undecided and gave reason of no benefits for not adopting cutting the old cocoa trees for replacement with new improved breeds while $26.67 \%$ of the respondents emphasized that the innovation will cut down their income since it will take close to ten (10) years for a new cocoa improved seedling to attain optimum production level. About $61.67 \%$ of the farmers used fertilizer on their farms and as a means to increase their production level. The study also reveals that $82.50 \%$ of the respondents declared adequate use of post harvesting techniques and emphasized that it enhance cocoa certification while $17.50 \%$ of the cocoa farmers were not adopting this technology in the sense that fermenting, drying and storage techniques were done indiscriminately without recommended approach.

Table 1: Socio Economic Characteristics of the Cocoa Farmers.

\begin{tabular}{lll}
\hline \multirow{2}{*}{ Characteristics } & \multicolumn{2}{c}{ Adopters } \\
\cline { 2 - 3 } Age Range (Years) & Frequency & Percentage \\
< 30 Years & 6 & 10.00 \\
$30-39$ Years & 12 & 20.00 \\
$40-49$ Years & 14 & 23.33 \\
$50-59$ Years & 7 & 11.67 \\
60 years above & 21 & 35.00 \\
& & \\
Sex of Respondents & & \\
Male & 47 & 78.33 \\
Female & 13 & 21.67 \\
& & \\
Secondary Occupation & & \\
Timber contractor & 5 & 8.33 \\
Welder & 3 & 5.00 \\
Trader & 17 & 28.33 \\
Mechanics & 3 & 5.00 \\
Electricians & 4 & 6.67 \\
\hline
\end{tabular}


International Journal of Agriculture and Environmental Research

ISSN: 2455-6939

Volume: 06, Issue: 06 "November-December 2020"

\begin{tabular}{lll}
\hline \multirow{2}{*}{ Characteristics } & \multicolumn{2}{c}{ Adopters } \\
\cline { 2 - 3 } & Frequency & Percentage \\
\hline Driver & 2 & 3.33 \\
Civil servant & 18 & 30.00 \\
Carpenter & 2 & 3.33 \\
Apprentice & 3 & 5.00 \\
Vulcanizer & 3 & 5.00
\end{tabular}

Farm Labour

Hired Labour

Family Labour

Improved Breeds

Planted

No planting

\section{Planting Mode}

Fully Planted

Partly Planted

No Planting

\section{Fungicides and Insecticides Usage}

1 time

2 times

3 times

4 times

$>4$ times

\section{Cutting Old Cocoa Trees}

No benefits

Cut down income

Not sure of benefits

Production risk

Expensive technology

\section{Use of Fertilzer}

Using fertilizer

No usage 
International Journal of Agriculture and Environmental Research

ISSN: 2455-6939

Volume: 06, Issue: 06 "November-December 2020"

\begin{tabular}{lcc}
\hline \multirow{2}{*}{ Characteristics } & \multicolumn{2}{c}{ Adopters } \\
\cline { 2 - 3 } & Frequency & Percentage \\
\hline Usage & 50 & 83.33 \\
No Usage & 10 & 16.67 \\
\hline
\end{tabular}

Source: Computed from field survey, 2020.

\subsection{Perceptive Use of Improve Cocoa Technologies among Farmers}

The ranking of the perceptive use of improved cocoa technologies in Table 2 was done by using five point scales to score farmers' responses. These scores are 5, 4, 3, 2 and 1 for strongly agree, agree, undecided, disagree and strongly disagree respectively. Generally, about 11 different statements on technology perceptive use were identified. The study indicates that the use of cultural maintenance practice to increase production of cocoa is most prominent among the farmers in the study area. This is closely followed by the use of fungicides and insecticides and the use of information sources on new methods to improve cocoa production respectively. The respective percentages of farmers using these technologies are $12.99 \%, 12.91 \%$ and $12.56 \%$. Moreover, a good number of respondents (11.35\%) indicated that adopting all the technologies will definitely boost cocoa production. The study reveals that the overall perception of the cocoa farmers is that using constantly cultural maintenance practices and agrochemicals on the farms will affect cocoa production positively. Meanwhile, the least perception of the farmers on the improved cocoa technology is the cutting of the old cocoa trees where only $4.55 \%$ of the respondents indicated its usage as one of the adopted improved cocoa technologies.

\subsection{Identified Constraints Militating Against the Use of Improved Cocoa Technologies}

High cost of adoption was ranked first among the constraints identified by respondents in the study area. Twenty- eight percents of the respondents emphasized on cost of adoption as the main challenge confronting the adoption of technologies. Unavailability of newly developed materials and tools that are useful on the farm such as; sprayer, mower, go-to-hell, extractors, pruning saw, and inputs such as; fungicide, insecticide, herbicide, fertilizer and the likes was ranked second as the constraints militating against adoption of improved cocoa technologies. Apart from this, lack of information; little or no contact with the extension agents and undeveloped pilot farm as a demonstration to farmers contribute to the reasons why farmers are not adopting the technologies. Low productivity and lack of technical skill on the farm were ranked third and fourth respectively. Moreover, these constraints go pari passu with technicality in management and skilled labour affecting the extent of fertilizers' application as recommended. Spraying of cocoa tree with fungicides and insecticides using newly modified sprayers; to mention but a few could be a factor for low cocoa production when the methodologies are not 
put into place on the farms. Respectively, about $15.93 \%$ and $12.64 \%$ of the respondents go for these constraints, however, the farmers attributed their yearly low production to lack of consistent and skilled labour, lack of information from the extension agents, high cost of production and unavailability of input/ materials. About $8.24 \%$ of the respondents identified the need for hire labours to assist on the farm while $5.49 \%$ of the respondents emphasized on lack of credit facilities as problems affecting adoption. About 4.40, 2.75 and $1.65 \%$ of the respondents have identified lack of incentives and remunerations; poor continuity and sustainability plan; and production gap for some years as the challenges they were facing on cocoa production respectively. And these have been ranked the seventh, eighth and ninth respectively.

\section{Table 2: Perceptive Use of Improve Cocoa Technologies among Farmers}

\begin{tabular}{|c|c|c|c|c|c|c|c|c|}
\hline \multirow[t]{2}{*}{ Statements } & \multicolumn{8}{|c|}{ Degree of agreement } \\
\hline & \begin{tabular}{|l} 
Strongl \\
y agree \\
5
\end{tabular} & $\begin{array}{l}\text { Agree } \\
4\end{array}$ & $\mathrm{~d}_{3}$ Undecide & $\mathrm{e}_{2}^{\text {Disagre }}$ & $\begin{array}{c}\text { Strongly } \\
\text { disagree } \\
1\end{array}$ & ${ }^{2}{ }^{T P U}$ & $\begin{array}{l}\% \text { of } \\
\text { Cocoa } \\
\text { farmers }\end{array}$ & Rank \\
\hline $\begin{array}{l}\text { a) Cutting of old cocoa } \\
\text { trees technology helps to } \\
\text { improve the production } \\
\text { and should be done }\end{array}$ & 0 & 3 & 13 & 10 & 34 & 105 & 4.55 & 11 \\
\hline $\begin{array}{l}\text { b) Even if it improves } \\
\text { production its } \\
\text { disadvantage is higher } \\
\text { than advantage }\end{array}$ & 15 & 36 & 9 & 0 & 0 & 246 & 10.65 & 6 \\
\hline $\begin{array}{l}\text { c) Cutting of the trees } \\
\text { could be done at any } \\
\text { height. }\end{array}$ & 0 & 2 & 14 & 22 & 22 & 116 & 5.02 & 9 \\
\hline $\begin{array}{l}\text { d) Replacing new } \\
\text { seedling by uprooting the } \\
\text { old one is better than } \\
\text { cutting to improve } \\
\text { production of cocoa }\end{array}$ & 1 & 3 & 14 & 13 & 29 & 114 & 4.94 & 10 \\
\hline \begin{tabular}{lr}
\multicolumn{1}{c}{ The } & use of \\
fungicides \& & insecticides \\
improves & cocoa \\
production
\end{tabular} & 58 & 2 & 0 & 0 & 0 & 298 & 12.91 & 2 \\
\hline 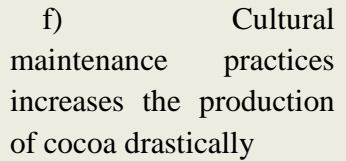 & 60 & 0 & 0 & 0 & 0 & 300 & 12.99 & 1 \\
\hline $\begin{array}{l}\text { g) Maintenance } \\
\text { practices is better off to } \\
\text { be adopted than any other } \\
\text { technology }\end{array}$ & 30 & 20 & 10 & 0 & 0 & 260 & 11.26 & 5 \\
\hline $\begin{array}{l}\text { h) Lack of information } \\
\text { affects cocoa production }\end{array}$ & 53 & 5 & 1 & 1 & 0 & 290 & 12.56 & 3 \\
\hline
\end{tabular}


International Journal of Agriculture and Environmental Research

ISSN: 2455-6939

Volume: 06, Issue: 06 "November-December 2020"

\begin{tabular}{|l|l|l|l|l|l|l|l|l|}
\hline $\begin{array}{c}\text { i) Adopting all the } \\
\text { technologies will } \\
\text { definitely boost cocoa } \\
\text { production }\end{array}$ & 38 & 10 & 8 & 4 & 0 & 262 & 11.35 & 4 \\
\hline $\begin{array}{l}\text { j) Intercropping cocoa } \\
\text { with other arable crops } \\
\text { affects production } \\
\text { negatively }\end{array}$ & 0 & 5 & 6 & 31 & 18 & 118 & 5.11 & 8 \\
\hline $\begin{array}{l}\text { k) Use of good } \\
\text { equipments/tools/ } \\
\text { implements and post } \\
\text { harvesting techniques } \\
\text { will definitely increase } \\
\text { cocoa production }\end{array}$ & 14 & 22 & 4 & 10 & 10 & 200 & 8.66 & 7 \\
\hline TOTAL & & & & & & $\mathbf{2 3 0}$ & $\mathbf{1 0 0 . 0}$ & \\
\hline
\end{tabular}

*multiple responses exist

Source: Computed from field survey, 2020.

Table 3: Constraints Militating against the Use of Cocoa Technologies

\begin{tabular}{lllc}
\hline Constraints & Frequency & Percentage & $\begin{array}{c}\text { Ascending } \\
\text { Order }\end{array}$ \\
\hline a) High cost of adoption & 51 & 28.02 & $1^{\text {st }}$ \\
b) Unavailability of materials/tool/inputs & 38 & 20.88 & $2^{\text {nd }}$ \\
c) Low productivity & 29 & 15.93 & $3^{\text {rd }}$ \\
d) Lack of technical skill & 23 & 12.64 & $4^{\text {th }}$ \\
e) Lack of hire labours & 15 & 8.24 & $5^{\text {th }}$ \\
f) No credit facilities & 10 & 5.49 & $6^{\text {th }}$ \\
g) Low incentives/remunerations & 8 & 4.40 & $7^{\text {th }}$ \\
h) Poor continuity and sustainability & 5 & 2.75 & $8^{\text {th }}$ \\
plan & & & $9^{\text {th }}$ \\
i) Production gap for some years & 3 & 1.65 & \\
\hline
\end{tabular}

*multiple responses exist

Source: Computed from field survey, 2020.

\section{CONCLUSION}

According to Ilesanmi J. O and Afolabi J. A. (2020) $21.10 \%$ of the respondents rated cultural maintenance practices as the best technology a farmer can adopt to increase cocoa production. This agrees with the Technology Perceptive Use Index (TPUI) model used to verify degree of agreement towards improved cocoa technologies in relation to farmers' perception that cultural maintenance practices increases the production of cocoa; and about $12.99 \%$ of the respondents agree with this. The least of the perception is the cutting of old cocoa trees technology which 
International Journal of Agriculture and Environmental Research

ISSN: 2455-6939

Volume: 06, Issue: 06 "November-December 2020"

helps to improve the production and should be done. About $4.55 \%$ of the respondents rated cutting of old cocoa tree technology to plant a new seedling so low due to the fact that they did not agree it can improve and boost cocoa production; and cutting down of income and uncertainty of benefits were attributed to the use of the technology.

The study indicated that the most identified constraints militating against the adoption of improved cocoa technologies is high cost of adoption since farmers in the study area were poor and unable to access funds both from formal financial institutions and cooperative societies.

\section{RECOMMENDATIONS}

Based on the findings of this study with regards to the first and second ranked statements, it is quite expedient to encouraged the cocoa farmers in Ekiti State to engage in Good Agricultural Practices (GAP) and Integrated Crop and Pest Management (ICPM) system which centers toward farmers' pruning to reduce pests and diseases; removing disease pods and burn them; constant inspection of farms to identify pests and diseases and spraying cocoa fields with insecticides only if other cultural measures do not help. And the knowledge of the above could be achieved by allowing cocoa farmers go through the Certification Capacity Enhancement (CCE) as a guide to be employed for better performance and to meet the requirements of the sustainability standards for Fairtrade, Rainforest Alliance and UTZ. Therefore, Extension agents, Agricultural professionals and Researchers, Agricultural NGOs and Input dealers should be encouraged to help farmers to ascertain the findings of this study for increase in cocoa production in Ekiti State. As regards the high cost of adopting cocoa technologies which is the major constraints identified by the cocoa farmers; government should increase access of the farmers to soft loans and funds or better off subsidizing the inputs and various technologies to be adopted through extension agents and Agricultural NGOs licensed with the state.

\section{REFERENCES}

1) Agbeniyi S. O., Ogunlade M. O. and Oluyole K. A. (2010). "Fertilizer Use and Cocoa Production in Cross River State, Nigeria”. ARPN Journal of Agricultural and Biological Science. Vol 5, No. 3, pp: $10-13$.

2) Ajemobi J. O. (2014) "Post-Liberalization Markets, Export Firm Concentration, and Price Transmission along Nigeria's Cocoa Supply Chain". AGRODEP. Retrieved 19 September 2015

3) Akintelu S. O. et al (2019). "Adoption of some cocoa production technologies by cocoa farmers in Kogi State, Nigeria". International Journal of Agriculture Innovation, Technology and Globalisation. DOI: 10.1504/IJAITG.2019.099602 
International Journal of Agriculture and Environmental Research

ISSN: 2455-6939

Volume: 06, Issue: 06 "November-December 2020"

4) Arndt, C., Jones, S. and Tarp, F. (2007), 'Aid and Development: the Mozambican Case', in Lahiri, S. (ed.), Theory and Practice of Foreign Aid, Frontiers of Economics and Globalization, Volume 1, Amsterdam: Elsevier.

5) EKSG (Ekiti State Government), About Ekiti (2016). Retrieved on 04/05/16 (available on: ekitistate.gov.ng/).

6) FAO (2013). "Analysis of Incentives and Disincentives for Cocoa in Nigeria". www.fao.org/mafap. Retrieved 19 September 2015.

7) Ilesanmi J. O., Afolabi J. A. (2020). "Determinants of Adoption of Improved Cocoa Technologies in Ekiti State, Nigeria”. International Journal of Agricultural Economics. Vol. 5, No. 2, 2020, pp. 36-42. doi: 10.11648/j.ijae.20200502.11

8) Islam, M. M. and M. A. Kashem (1999) Farmers use of Ethno-veterinary Medicine $(\mathrm{EVM})$ in the rearing and management of livestock: An Empirical Study in Bangladesh, Journal of Sustainable Agriculture, Vol. 13, No.4 pp. 39-56.

9) Lawal J. O. and Oluyole K. A. (2008). Factors Influencing Adoption of Research Results and Agricultural Technologies Among Cocoa Farming Households in Oyo State, Nigeria. Int. J. Sustain. Crop Prod. 3(5): $10-12$

10) Mwannga, J., A. Mussie,W. Mwangi and H. Verkuijl (1998) "Adoption of improved wheat technologies by small-scale farmers in Mbeya district of southern highlands, Tanzania." A paper presented at wheat workshop for eastern, central and southern Africa. University of Stellenbosch, South Africa, 14-18 September 1998.

11) National Population Commission, (2006) Census. Federal Republic of Nigeria, December, 2006.

12) Ndubuakwu T. C. N and E. U Asogwa (2006). "Strategies for the control of Pests and Diseases for sustainable Cocoa production in Nigeria". Entomology Group Cocoa Research Institute of Nigeria, Ibadan, Nigeria. African Scientist Vol. 7, No 4, December 31, 2006. AFS2006033/7409.

13) Ofori-Boateng, K., \& Insah, B. (2014). The impact of climate change on cocoa production in west africa. International Journal of Climate Change Strategies and Management, 6(3), 296

14) Oguntade M.O., K.A. Oluyole and P.O. Aikpokpodion. (2009). An Evaluation of the Level of Fertilizer Utilization for Cocoa Production in Nigeria. Journal of Human Ecology. 25(3): 175-178.

15) Ojo A (2005). The problem of cocoa marketing and trade in Nigeria: Pre- liberalization and liberalization era. Cocoa Occasional publication number 2.

16) Olson R.A. (1970). The Fertilizer Programme of Freedom from Hunger Campaign. In: A.H. Bunting (Ed): Change in Agriculture. Duckworth and Co. Ltd., London. pp. 599605. 
International Journal of Agriculture and Environmental Research

ISSN: 2455-6939

Volume: 06, Issue: 06 "November-December 2020"

17) Oluwatayo, I. B. (2009) Gender Considerations in Decision Making in Rural Nigeria: Implications on Households' Food Security in Ekiti State. Department of Agricultural Economics and Extension Services, University of Ado-Ekiti, P.M.B. 5363, Ado-Ekiti, Ekiti State, Nigeria.

18) Oluyole K. A and Lawal, J.O, (2008)."Determinants of the Occurrence of Blackpod Disease of Cocoa in Edo State, Nigeria: A multivariate Probit Analysis Approach. J. Innovation and Development Strategy, 2(2): 1 - 4.

19) Oluyole K.A., Egbetokun O.A., Oni O. A., and Aigbekaen E.O. (2011) Technological Changes and Labour Demand among Cocoa Farmers in Nigeria 1Cocoa Research Institute of Nigeria, P.M.B. 5244, Ibadan, NigeriaWorld Journal of Agricultural Sciences 7 (5): 638-641, 2011 ISSN 1817-3047 @ IDOSI Publications, 2011

20) Opeke, L. K. (2003). Increasing Cocoa Production in Nigeria during the Third Millenium. Occasional Publication, Cocoa Association of Nigeria (CAN), Akure, Ondo State, Nigeria.

21) Opeyemi AA., Fidelis OA., Ademola B, Philip O (2005). Quality Management Practices in Cocoa Production in South-Western Nigeria. Conference on International Research on Food Security, Natural Resource Management and Rural Development.

22) Verter, N.; Bečvářová, V. (2014). "Analysis of Some Drivers of Cocoa Export in Nigeria in the Era of Trade Liberalization". Agris on-line Papers in Economics \& Informatics. 6 (4): 208-218.

23) Vos J. M, Krauss U. (2004). Working with farmers. Cocoa futures. A source book of some important issues controlling the cocoa industry. Flood J, Murphy R Eds. Feriva SA Cali Columbia CABI Commodities. An Initiative of CABI Bioscience. Colombia. The Commodities Press. Chapter 12: 141-149.

24) Wikipedia Online Encyclopedia, (2010), https://en.wikipedia.org/wiki/Ekiti_State. Edited on 14/07/2020. Retrieved on 27/07/2020. 